BBA 96345

\title{
ENZYMATIC SYNTHESIS OF CARBONIC ANHYDRASES BY HUMAN RETICULOCYTES
}

\author{
N. L. MEYERS, G. J. BREWER AND R. E. TASHIAN \\ Departments of Human Genetics and Medicine (Simpson Memorial Institute), University of Michigan \\ Medical School, Ann Avbor. Mich. (U.S.A.)
}

(Received May 5th, Ig69)

\section{SUMMARY}

Human reticulocyte-rich blood incubated $4 \mathrm{~h}$ at $37^{\circ}$ in $\mathrm{O}_{2}-\mathrm{CO}_{2}(95: 5, \mathrm{v} / \mathrm{v})$ with ${ }^{3} \mathrm{H}$ - or ${ }^{14} \mathrm{C}$-tagged amino acids revealed incorporation of the label into carbonic anhydrase $\mathrm{I}$ and $\mathrm{II}, \mathrm{Hb} \mathrm{A}$, and in one patient, into $\mathrm{Hb} \mathrm{S}$. No radioactivity could be detected in normal, nonreticulocyte-rich blood similarly treated. From this, it is concluded that the anucleate human reticulocyte synthesizes carbonic anhydrase I and II by means of a stable messenger RNA in the absence of DNA.

During the course of this study, several new methods were developed for the microanalysis of proteins including ( $\mathrm{I}$ ) comparison of labeled protein components after electrophoresis by liquid scintillation counting of consecutive slices of starch gels with autoradiography, (2) isolation of I-mg quantities of carbonic anhydrase from whole blood hemolysates followed by tryptic digestion and fingerprinting of o.or mg samples on thin-layer chromatography support sheets, and (3) autoradiographs of the fingerprints by apposition to ARIo film plates and recording the film reduction by light microscopy and photomicrography.

\section{INTRODUCTION}

For the first $24-48 \mathrm{~h}$ after the anucleate mammalian erythrocyte is released into the circulation from the bone marrow, it contains a "reticulum" consisting of RNA and is called a reticulocyte. Studies of human and rabbit reticulocytes have shown that they synthesize hemoglobin ${ }^{1}$, but little is known regarding the synthesis of other proteins. One of our objectives was to study labeled amino acid incorporation into enzymes by reticulocytes to determine if the synthesis of hemoglobin is exceptional or if other proteins are also synthesized. Another objective was to develop micro fingerprinting which, together with autoradiographic methods, could be useful in the structural study of enzymes present in trace amounts.

The enzyme selected for initial study was carbonic anhydrase because it is a relatively stable enzyme and because it is present in higher amounts in the human red cell than any other enzyme. Furthermore, the two-dimensional tryptic peptide patterns ("fingerprints") of the two isozymes of carbonic anhydrase, carbonic anhydrase I and carbonic anhydrase II (also referred to as carbonic anhydrase B and carbonic anhydrase $\mathrm{C}$, respectively (cf. ref. 2)) had been previously demonstrated by the usual macroscopic methods ${ }^{3}$. 


\section{MATERIALS AND METHODS}

Scintillation fluid was supplied by Packard Instrument Co., Box 428, La Grange, Ill.

Thin-layer glass microfiber support sheets, of fiberglass impregnated with silica gel, came from Gelman Inc. (Ann Arbor, Mich.). ${ }^{14} \mathrm{C}$-tagged amino acids were purchased from Tracerlab (Waltham, Mass.). It is a purified algal protein hydrolysate consisting of $\mathrm{I} 5$ amino acids. Concentration is $0.1 \mathrm{mC} / \mathrm{ml}$ in $0.1 \mathrm{M} \mathrm{HCl}$ solution. Reconstituted ${ }^{3} \mathrm{H}$-labeled protein hydrolysate was obtained from Schwarz BioRes. (Orangeburg, N.Y.). It contains $\mathrm{I} 6$ amino acids in o.or $\mathrm{M} \mathrm{HCl}, \mathrm{I} \mathrm{mC} / \mathrm{ml}$.

ARIo film was obtained from Kodak (London). It consists of an unprotected emulsion layer $5 \mu$ thick on a Io- $\mu$ gelatin layer and is ordinarily stripped from its glass base in the dark onto microscope slides containing stained tissue sections. The thicker AR 50, about Io times more sensitive but coarser grained, could not be employed successfully by our processing method.

Blood rich in reticulocytes (ro-40\%) was obtained from patients with hemolytic anemia. Io-ml samples of normal and reticulocyte-rich blood were drawn into heparinized tubes. After centrifugation for Io min at Iooo $\times g$, the plasma was temporarily removed, the buffy coat aspirated and the plasma replaced. To each Io-ml sample was added $\mathrm{I} \mathrm{ml}$ of $5 \%$ glucose solution and $0.4 \mathrm{ml}$ of neutralized amino acid solution labeled with $0.2 \mathrm{mC}$ of ${ }^{3} \mathrm{H}$ (or $0.05 \mathrm{mC}{ }^{14} \mathrm{C}$ ). A control aliquot of each sample was also carried through every step in the process except that an equivalent amount of saline was substituted for the labeled amino acid solution. A gas mixture of $\mathrm{O}_{2}-\mathrm{CO}_{2}(95: 5, \mathrm{v} / \mathrm{v})$ was bubbled slowly through the samples. ${ }^{4}$ Throughout the incubation $\left(4 \mathrm{~h}\right.$ at $\left.37^{\circ}\right)$ the $\mathrm{pH}$ was approx. 7.4. After incubation and removal of the plasma layer, the erythrocytes were washed twice with physiological saline, suspended in an equal volume of distilled water and lysed by freeze-thawing three times to assure the complete rupture of the reticulocytes.

The hemolysate was then treated with 0.4 vol. of toluene held in a Vortex spinner for I min and centrifuged for I5 min at I000 $\times \mathrm{g}$; the toluene layer was aspirated, and excess unincorporated labeled amino acids were removed by dialysis against distilled water for $\mathrm{I} 6 \mathrm{~h}$ at $4^{\circ}$. The sample was concentrated to about $0.5 \mathrm{ml}$ in partial vacuum for several hours in the cold. It was then centrifuged at $36000 \times \mathrm{g}$ for $30 \mathrm{~min}$, and the clear supernatant was removed and stored at $4^{\circ}$ until use.

Aliquots (about $25 \mu \mathrm{l}$ ) were placed on starch gels for vertical electrophoresis

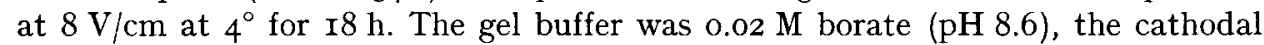
bridge buffer was $0.3 \mathrm{M}$ borate $(\mathrm{pH} 8.0$ ) and the anodal bridge buffer was $0.3 \mathrm{M}$ $\mathrm{NaCl}$. There was no evidence of contamination by radioactivity diffusing across the gel. Starch gels were sliced horizontally with one half stained for protein with $4 \%$ nigrosin and the other for the esterase activity of carbonic anhydrase ${ }^{5}$. A photographic record was made of both halves.

\section{Liquid scintillation counting}

Either the protein (nigrosin) or carbonic anhydrase (esterase) stained half of the gel was divided into longitudinal strips representing the electrophoretic path of each sample. The strip was cut into numbered sections of $0.3-0.5 \mathrm{~cm}$ in length ${ }^{6}$ which were placed into scintillation vials and dried slowly for about $2 \mathrm{~h}$ (IOO-IIO ${ }^{\circ}$. Con- 
trolled experiments showed that neither the nigrosin nor the azo-coupling esterase dye, Blue RR, interfered with the scintillation count. After a short period of cooling, the dried starch sections were covered with $2-5 \mathrm{ml}$ of scintillation fluid $(0.6 \% \mathrm{I}, 4$-bis2-(5-phenyloxazyl)benzene and $0.03 \%$ I,4-bis-(4-methyl-5-phenyloxazolyl)benzene in dry toluene). In this two-phase system, care is needed to prevent quenching by aqueous contamination. Radioactivity was determined in a Packard 3003 Tri-Carb scintillation spectrometer by running I0-, 20- and 50-min counts. The scintillation peaks were then related to the protein bands known to correspond to the hemoglobin and carbonic anhydrases (Fig. I).

\section{Autoradiography with $A R$ Io stripping film plates}

Autoradiographs of starch gels containing ${ }^{3} \mathrm{H}$ - and ${ }^{14} \mathrm{C}$-tagged proteins emitting low-energy $\beta$ rays with short path of travel were obtained by bringing the sensitive, fine-grain film ( $22 \mathrm{~cm} \times \mathrm{I} 6 \mathrm{~cm}$ ) directly into contact with the partially dried starchgel surface. The total area of the film was thus utilized without the customary stripping, and the whole procedure was easily accomplished in the dark room by supporting the starch on a clean glass plate or other smooth surface. The glass base of the AR Io film formed an opposite surface so that the whole could be incubated in a light-tight container at $4^{\circ}$ for about 2 weeks. The film plate was removed in the dark room, developed in glass trays, emulsion side up, using $D$-Ig developer for $5^{-6}$ min, rinsed in water IO-I5 sec, then in "Rapid Fixol" 2-3 min (twice the time to clear) and finally washed in three successive water rinses for about 30 sec each. All the solutions were at $I 8-I 9^{\circ}$, and the trays were tipped frequently to assure stirring. In the above procedures, care must be taken (a) to use rubber gloves to avoid radiation contamination, (b) to touch the film plates only at the glass edges in order to preserve the unprotected emulsion and (c) to dry the film plates in an upright position in dust-free air. In this manner, a clear, adhering emulsion surface is obtained from which radiation darkened areas may be observed, studied under the microscope with dry objectives and photographed (Fig. 2 and 3). Thin-layer chromatographic plates and sheets containing labeled material may be similarly incubated with AR-Io film plates and developed as described above. Two types of control were run: (a) film which had not been removed from its original wrapping and (b) film placed in apposition to a nonradioactive electrophoretic gel or thin-layer chromatographic support. Such controls were clear and showed no silver grain reduction when inspected visually or with light microscopy.

\section{Isolation of carbonic anhydrases from ${ }^{\mathbf{1 4}} \mathrm{C}$-tagged reticulocyte-rich hemolysates}

This method was modified from that of Tashian et al., ${ }^{3,5}$. Approx. $\mathrm{r}-2 \mathrm{ml}$ of the hemolysate were placed in a glass-stoppered $25-\mathrm{ml}$ graduate and extracted with I vol of $40 \%$ ethyl alcohol and 0.5 vol. of chloroform poured simultaneously into the mixture. To prevent emulsion formation, the container was tipped and shaken intermittently for about Io min while trapped gases were released by removing the stopper occasionally. After refrigeration for about $20 \mathrm{~min}$, the clear supernatant was removed from the solid plug with a Pasteur pipet. Further purification was achieved by eluting from a DEAE-cellulose column using $3 \cdot \mathrm{IO}^{-3} \mathrm{M}$ phosphate buffer $(\mathrm{pH} 7.02)$ followed by a DEAE-Sephadex A-50 column in $0.05 \mathrm{M}$ Tris- $\mathrm{HCl}$ buffer $(\mathrm{pH} 8.7)$. The glass microcolumns $(0.5 \mathrm{~cm} \times 46 \mathrm{~cm})$ were fitted with a base of fine nylon mesh 
and with a I4-cm funnel at the top which contained a wide paddle stirrer. Best results were obtained with a dilute suspension of the column material stirred continuously at a slow constant rate during the filling of the column. After temperature equilibration at $4^{\circ}$, the carbonic anhydrase fraction concentrated to $\mathrm{I}-2 \mathrm{ml}$ was placed on the column and eluted with the suspension buffer at $4^{\circ}$. In one run, I24 fractions of $0.5 \mathrm{ml}$ each were collected at 3 -min intervals, and all were read for absorption at $280 \mathrm{~m} \mu$ in a Zeiss spectrophotometer. The expected separation of carbonic anhydrase II (which is eluted prior to carbonic anhydrase I) was not detected with the small amounts of sample employed. Fractions 57-75 showed significant readings with a peak at Fraction 69; the combined fractions gave a positive test for carbonic anhydrase activity using a simplified bromthymol blue staining test ${ }^{7,8}$.

\section{Thin-layer fingerprinting of the tryptic digest of carbonic anhydrase}

The combined enzyme fraction was concentrated to about $\mathrm{I} \mathrm{ml}$ in dialysis tubing at reduced pressure and $4^{\circ}$ in preparation for tryptic digestion. The amount of carbonic anhydrase present was calculated from the absorbance, the known extinction coefficient of human carbonic anhydrase I, (48 goo), and the accepted molecular weight of 30000 (ref. 2,9 ). The calculated amount of $1.2 \mathrm{mg}$ obtained from about $\mathrm{I} \mathrm{ml}$ of cells was in fair agreement with reported values of $\mathrm{I} .6 \mathrm{mg}$ from $\mathrm{I} \mathrm{ml}$ of packed cells ${ }^{5}$.

After denaturation of the protein at $95^{\circ}$ for 3 min, trypsin was added at a ratio of $2 \%$ of the enzyme and incubated for $2 \mathrm{~h}$ at $37^{\circ}$. The slightly cloudy supernatant following tryptic digestion was centrifuged at $1000 \times g$ for $30 \mathrm{~min}$, and then the clear supernatant was removed and concentrated to about $0.5 \mathrm{ml}$ in a vacuum desiccator at reduced pressure over $\mathrm{NaOH}$ pellets.

Two-dimensional tryptic peptide patterns were obtained on glass microfiber, thin-layer chromatographic support sheets impregnated with silica gel (Gelman ITLC, Type SA, $20 \mathrm{~cm} \times 20 \mathrm{~cm}$ ) (Fig. 4.). The sheet (handled only with clean gloves) was prepared by immersing it in a buffer of concentrated formic acid-glacial acetic acid-water, $(25: 75: 400, \mathrm{v} / \mathrm{v} / \mathrm{v}, \mathrm{pH}$ I.8) and then by blotting well between Whatman No. I filter paper. Filter paper "wicks" cut to fit and carry the current from the electrode troughs were treated similarly. The thin-layer chromatographic sheet was placed carefully into position on a plastic holder in the dry electrophoresis chamber. About $0.002-0.003 \mathrm{ml}$ of the concentrated tryptic digest were placed sequentially with a I- $\mu$ l pipet without drying, on a point $2.5 \mathrm{~cm}$ from the margins (to allow for cathodal migration). The same thin-layer chromatographic refrigerated buffer was also used in the electrophoresis compartments, and the slightly moist wicks were kept in position with the aid of glass plates. The box was closed and equilibration was rapid in the small space; current was applied when the buffer front was observed to just reach the area of the sample (this avoids diffusion) and was continued for $75^{-90} \mathrm{~min}$ at $500 \mathrm{~V}, \mathrm{I} 8-22 \mathrm{~mA}$. At room temperature, very little heat developed. The thin-layer chromatographic sheet was removed and dried (upright position) in a well-ventilated hood for ${ }_{5} \mathrm{~min}$, followed by accelerated drying in an oven with circulating air up to $80^{\circ}$ to remove all volatile solvents. Alternatively, the sheet was dried at room temperature overnight ( $c f$. ref. Io).

For the chromatography phase, the dried thin-layer chromatographic sheet was equilibrated in a Gelman chromatography chamber with the solvent mixture, 
$n$-butanol-glacial acetic acid-water $(3: \mathrm{I}: \mathrm{I}, \mathrm{v} / \mathrm{v} / \mathrm{v}, \mathrm{pH} 2.5)$ for $30 \mathrm{~min}$ followed by ascending chromatography for about $2 \mathrm{~h}$. The thin layer chromatographic sheet was air dried as described above (after electrophoresis) and then sprayed with $0.3 \%$ ninhydrin-acetone solution containing I \% each of pyridine and acetic acid as catalyst $(\mathrm{v} / \mathrm{v})$. Care was taken to prevent overspraying or overheating in the drying process $\left(80^{\circ}\right.$ is maximum with the Gelman ITLC sheets) to avoid the formation of a pink background. The completely dried fingerprint was then examined, marked and photographed immediately since the pattern fades quickly, especially with very low concentration of peptides. The fingerprint was then incubated with AR-Io film plates as described above (cf. ref. II).

\section{RESULTS}

The liquid scintillation counts of starch gel patterns cut into narrow consecutive sections are shown in Fig. I for Patient $I$, who had $43 \%$ reticulocytosis. A plot of counts/min versus sample number revealed peaks of radioactivity in those areas of the gel which had been identified by previous staining to be the two isozymes of carbonic anhydrase, carbonic anhydrase I and carbonic anhydrase II, while the incorporation of label into $\mathrm{Hb} \mathrm{A}$ was about four times as great as carbonic anhydrase $\mathrm{I}$. Since this patient was also heterozygous for sickle-cell hemoglobin, $\mathrm{Hb} \mathrm{S}$ also appeared in the starch gel pattern, and its $\beta$ ray emission was equal in amount to that of carbonic anhydrase I.


Fig. r. Patient 1 reticulocyte hemoglobin and carbonic anhydrase (CA) as shown by liquid scintillation counting of gel sections. The blood had been incubated with a labeled mixture of amino acids and then subjected to starch gel electrophoresis. The origin of the gel application was between the points labeled $\mathrm{Hb} \mathrm{A}_{2}$ and $\mathrm{CA}$. The anodal end is at the right of the figure. Absolute data has been plotted and the background is 10.3 counts $/ \mathrm{min}$.

Fig. 2. Starch-gel electrophoresis pattern of ${ }^{14} \mathrm{C}$-labeled reticulocyte-rich hemolysate (right side) stained for protein and then incubated with AR io film plate, compared with a nonlabeled control sample (left side). The stippling in the labeled areas indicate the faintly visible silver grain reduction on the autoradiograph. $\mathrm{CA}=$ carbonic anhydrase.

Biochim. Biophys. Acta, I95 (1969) I76-185 

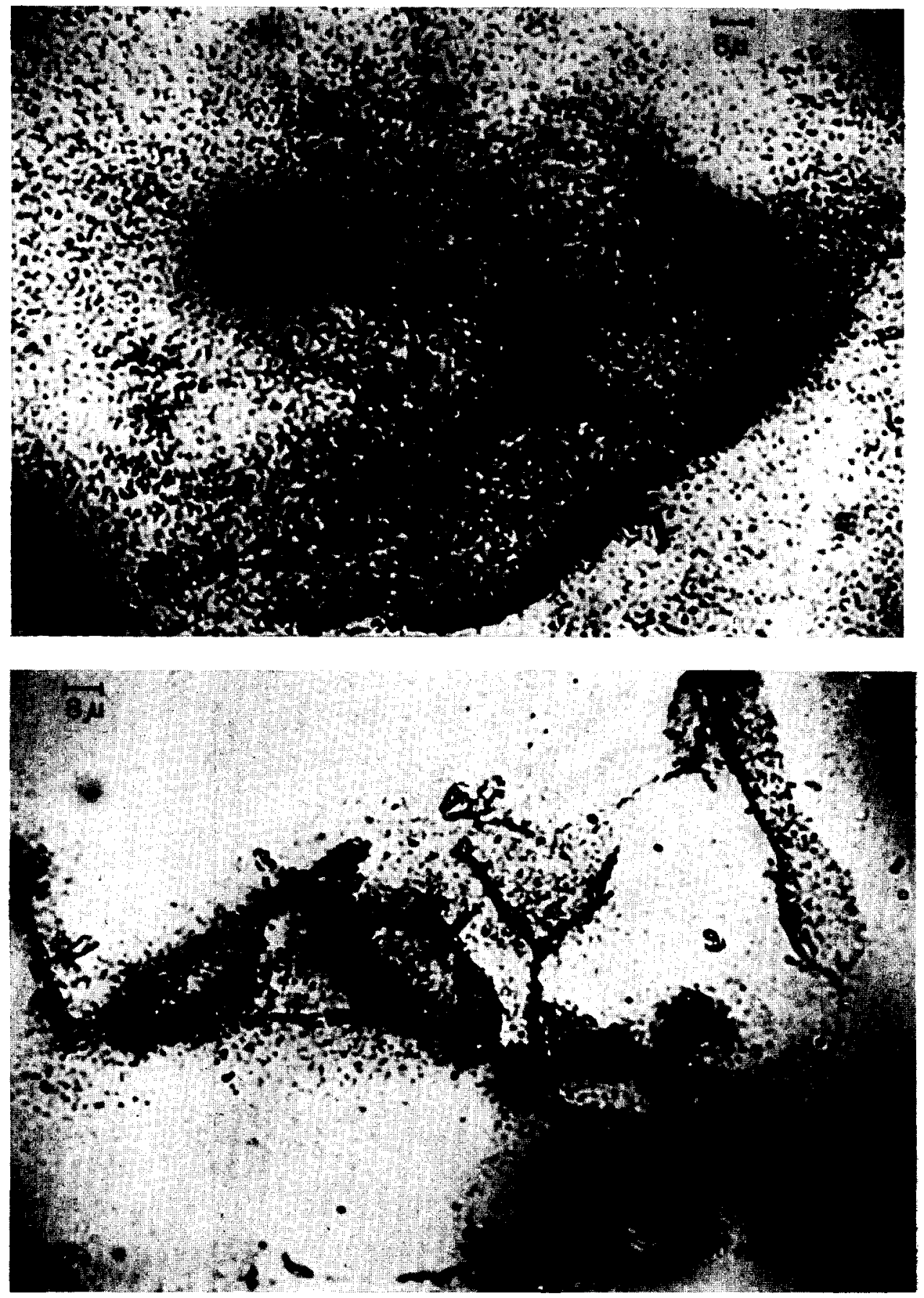

Fig. 3. Photomicrographs of labeled areas of Fig. 2 seen under the microscope verify the dense reduction of the film in (a) the $\mathrm{Hb} \mathrm{A}$ zone ( $75^{\circ} \times$ magnification) and in (b) the lesser radioactivity from carbonic anhydrase I $(600 \times)$. The pattern in (b) is due to gel surface shrinkage during the incubation period. 


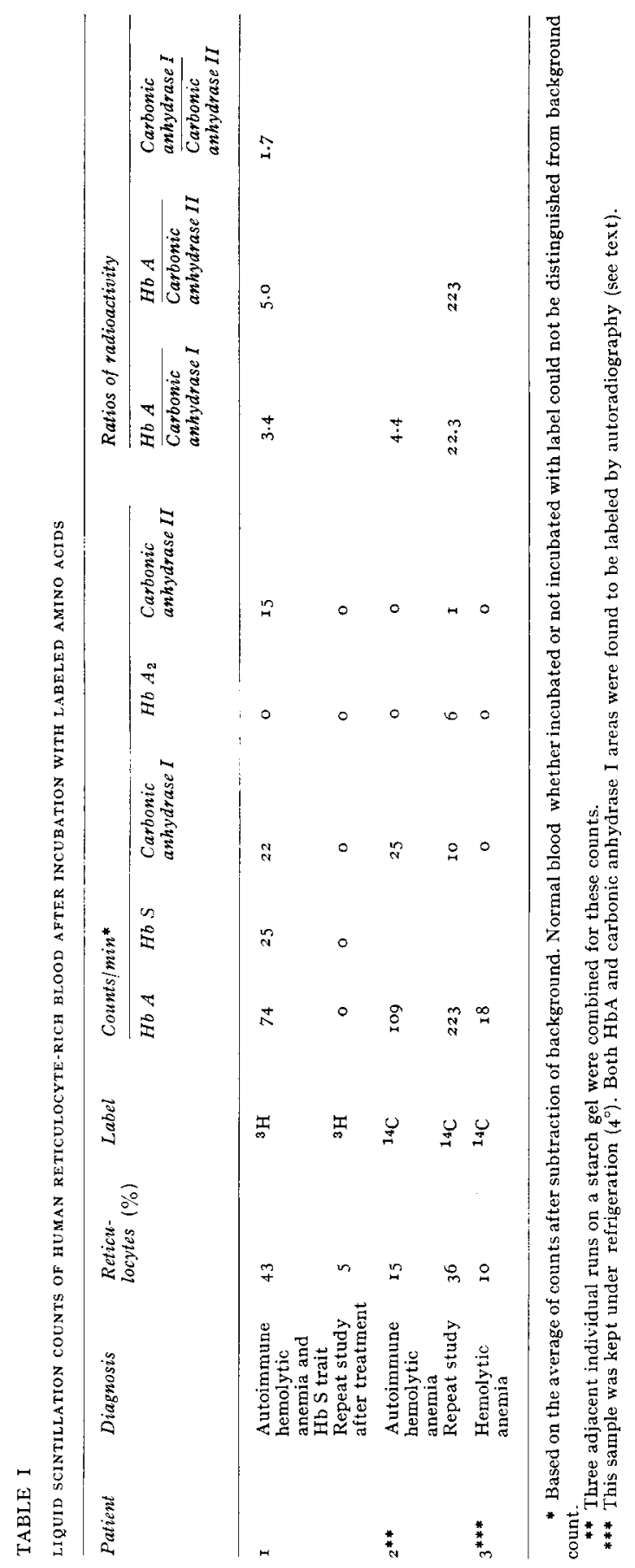

Biochim. Biophys. Acta, 195 (1969) $17^{6-185}$ 
After therapy, when the reticulocyte count of Patient I had fallen to $5 \%$, his scintillation scan was similar to that of control nonreticulocyte-rich blood, i.e. radioactivity could not be distinguished from the background count.

Fig. 2 shows a starch gel electrophoresis pattern of ${ }^{14} \mathrm{C}$-labeled material after autoradiography contrasted with nonlabeled control sample. Silver grain reduction was only faintly visible to the eye, but was clearly apparent under the microscope (Fig. 3). The use of the photomicrographs to increase the sensitivity of the autoradiographic method for this application represents an extension of microscope slide autoradiography. Quantitation of the distribution of label as seen through the microscope has not as yet been attempted but should be feasible, both with starch gels and the detection of radioactivity on thin-layer chromatographic plates (Fig. 5).

Table I shows that in every patient with significant reticulocytosis (Io \% or greater) the cells had synthesized carbonic anhydrase I. Carbonic anhydrase II synthesis was also detectable in the case with the highest percentage of reticulocytosis (Patient $\mathrm{I}, 43 \%$ ). It is noteworthy, however, that absolute radioactivity did not parallel exactly the degree of reticulocytosis ${ }^{\mathbf{1 2}}$, and variation in the ratios of proteins synthesized reflected this: e.g. Patient 2 with $\mathrm{I}_{5} \%$ reticulocytes had a higher synthesis ratio of $\mathrm{Hb}$ A to carbonic anhydrase I than did Patient $\mathrm{I}$, and when the reticulocytosis of Patient 2 rose to $36 \%$, there was a more marked increase in the $\mathrm{Hb} \mathrm{A}$ to carbonic anhydrase I ratio, while a small amount of $\mathrm{Hb} \mathrm{\textrm {A } _ { 2 }}$ was also detected.

In all cases carbonic anhydrase I synthesis rates were greater than for carbonic anhydrase II in keeping with the value of the relative amounts of carbonic anhydrase I: carbonic anhydrase II of $5: \mathrm{I}$.

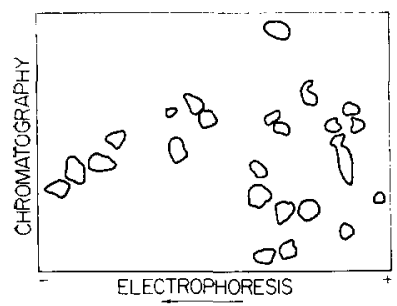

Fig. 4. Ninhydrin-stajned thin-layer two-dimensional chromatograph of the tryptic peptides of the carbonic anhydrase fraction isolated from human reticulocyte blood (Io \%) after incorporation of ${ }^{14} \mathrm{C}$-labeled amino acids. Cathodal migration is from right to left.

Fingerprints of the tryptic peptides of carbonic anhydrase I on Gelman fiber glass support sheets were better resolved and more reproducible in lower $\mathrm{pH}$ buffers and solvent systems than those based on pyridine. The ninhydrin stained fingerprint (Fig. 4) of the tryptic peptides from the carbonic anhydrase fraction isolated from hemolysates showed the total enzyme fraction obtained from both lysed erythrocytes and reticulocytes. The autoradiographs and photomicrographs (Fig. 5) from the film surface further confirmed the labeled carbonic anhydrase portion synthesized by the reticulocytes during the incubation period with the mixture of tagged amino acids. 


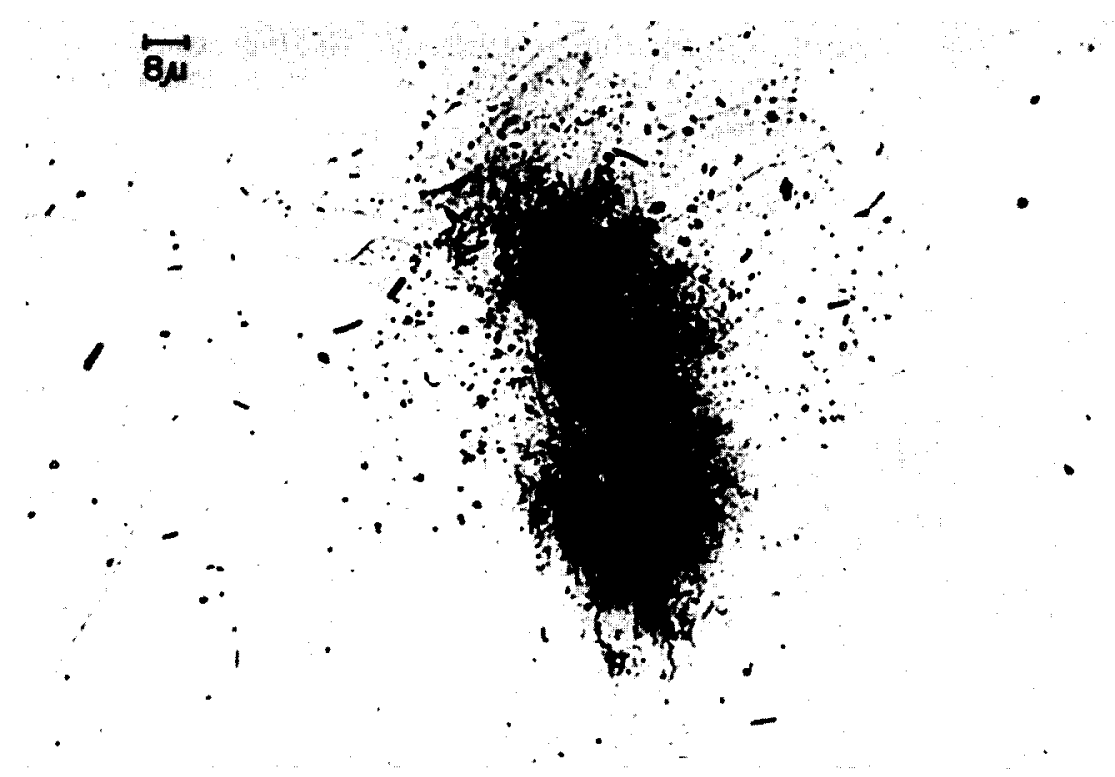

Fig. 5. Typical photomicrograph of silver grain reduction by a peptide in the autoradiograph obtained from the fingerprint of labeled carbonic anhydrase $(420 \times)$.

\section{DISCUSSION}

Circulating blood normally carries a complement of about I \% reticulocytes in equilibrium with replacement demands for aged erythrocytes. The reticulocyte in the circulation requires about 2 days to mature, i.e. it loses its "net" of the RNA messenger proteins, and becomes an anucleate erythrocyte. It previously has been documented that the mammalian reticulocyte can synthesize hemoglobin. We have shown that carbonic anhydrase I and II are also produced.

Beyond simple percentage of reticulocytes however, other factors must also operate to determine the amount of synthesized $\mathrm{Hb}$ and carbonic anhydrase I detectable in our system ${ }^{\mathbf{1 3}, \mathbf{1 4}}$. The ratio of these two proteins is also variable: Thus $\mathrm{Pa}$ tient I with a greater reticulocytosis of $43 \%$ had a smaller ratio of $\mathrm{Hb} \mathrm{A}$ to carbonic anhydrase I (3.0) than did Patient 2 with a surprisingly high (22.0) ratio at $36 \%$ reticulocyte count.

\section{Sensitivity of the methods}

These methods appear to be quite sensitive. Even without separation of the reticulocytes from whole blood, it was possible to record carbonic anhydrase synthesis. Although the best results were obtained by incubating the sample as soon as feasible after drawing, we nevertheless were able to record incorporation of the label in a sample of blood with Io \% reticulocytosis (Patient 3) which had stood overnight in refrigeration. In this case, autoradiography reinforced the scintillation data by showing the inclusion of tagged amino acids at $\mathrm{Hb} \mathrm{A}$ and carbonic anhydrase $\mathrm{I}$ bands in starch gels (Fig. 2). It seems apparent that the methods can be made even more sensitive by simple reticulocyte separation and concentration methods. Beyond 
this, in the study of animal systems, where reticulocytosis of $60 \%$ or more can routinely be obtained, the method should be quite applicable to the study of many red cell proteins.

Our thin-layer chromatographic fingerprints of the tryptic digest of isolated carbonic anhydrase using $0.0 \mathrm{I}-0.03 \mathrm{mg}$, and greatly shortened elapsed time, makes possible not only a saving of materials but permits the exploration of blood enzymes present in much smaller concentrations than carbonic anhydrase.

The autoradiography results were best ascertained by microscope examination of the film surface for silver grain reduction and by photomicrography. This method may prove to be a more sensitive tool for revealing labeled enzymes and other proteins present in trace amounts than simply visual inspection. It is in fact an extension of microscope slide autoradiography; thus a complete fingerprint of tryptic peptides may be autoradiographed and photomicrographed. Finally autoradiographic methods will help distinguish between the total protein as seen by staining methods and that portion which has incorporated a labeled metabolite.

\section{ACKNOWLEDGMENTS}

This work was supported in part by the Michigan Memorial Phoenix Project No. 388, in part by U.S. Public Health Service research grant AM 0938I, U.S. Public Health Service Career Development Award I-K3-AM-7959(G.J.B.) and by U.S. Public Health Service I-POI-GM-I54I9-02.

\section{REFERENCES}

I H. M. Dintzis, Proc. Natl. Acad. Sci. U.S., 47 (I96I) 247.

2 E. E. Rickli, S. A. S. Ghazanfar, B. H. Gibbons and J. T. Edsall, J. Biol. Chem., 239 (I964) I065.

3 R. E. Tashian, D. C. Shreffler and T. B. Shows, Ann. N. Y. Acad. Sci., i 5 I (i968) 64.

4 J. C. Gall, JR., G. J. Brewer and R. J. Dern, Am. J. Human Genet., I 7 (I965) 359.

5 R. E. Tashian, S. K. Riggs and Y. L. Yu, Arch. Biochem. Biophys., I 7 (I966) 320.

6 S. Funa Koshi and H. F. Deutsch, J. Biol. Chem., 243 (1968) 6474.

7 O. Pihar, Collection Czech. Chem. Commun., 30 (I965) 3220.

8 R. E. TAshian, in J. J. Yunis, Biochemical Methods in Red Cell Genetics, Academic Press, New York, 1969, p. 307.

9 T. H. Maren, Psysiol. Rev., 47 (1967) 597.

ro G. Patakr, Techniques of Thin-Layer Chromatography in Amino Acid and Peptide Chemistry, Ann Arbor Science Publishers, Ann Arbor, Mich., revised ed. (in English), 1966, p. 98.

I I A. W. Rogers, Techniques of Autoradiography, Elsevier, Amsterdam, 1967, p. 240.

I E. R. Burka And P. A. Marks, Blood, 30 (I967) 405.

I3 A. Miller and A. B. Maunsbach, Science, i5 I (1966) 1000.

I4 H. A. Itano, J. Cellular Comp. Physiol., 67 (1966) 65. 